\section{Plastic Mulch and In-row Spacing Effects on Sweetpotato Yield in Northwest Washington}

\author{
Srijana Shrestha ${ }^{1}$ and Carol Miles ${ }^{1}$
}

Additional index words. Agriotes sp., Ipomoea batatas, Limonius sp., polyethylene mulch, slips, soil-biodegradable mulch, soil temperature, wireworm

Summary. Sweetpotato (Ipomoea batatas) production in the northern United States is limited due to the perceived barriers of a short growing season and relatively cool summer temperatures, yet recent studies have shown yield in northern regions can be greater than the national average when sweetpotatoes are grown with plastic mulch. A study was conducted in northwest Washington to evaluate the productivity of 'Covington' sweetpotato with polyethylene (PE) and soil-biodegradable (BDM) mulches and different in-row spacings $(20,30$, and 38 $\mathrm{cm}$ ) in 2019, and to test accessions resistant to wireworm (Agriotes sp. and Limonius sp.) in 2020. In 2019, slips were shipped from North Carolina, and after 4 days in transit, $60 \%$ to $70 \%$ died after transplanting in the field. By the end of the season, BDM deterioration reached $11 \%$ compared with $0.4 \%$ for PE mulch, but there were no differences due to mulch in plant establishment, growth, yield, or the proportion of storage roots damaged by wireworm. Total storage root yield was $22 \mathrm{t} \cdot \mathrm{ha}^{-1}$ with $\mathrm{PE}$ mulch and $15 \mathrm{t} \cdot \mathrm{ha}^{-1}$ with BDM. Percent canopy cover was greatest at $20-\mathrm{cm}$ spacing later in the growing season, likely due to intermingling of vines from adjacent plants, whereas high percent canopy cover at $38-\mathrm{cm}$ spacing was likely due to increased production of secondary vines per plant. Total yield was greatest with $20-\mathrm{cm}$ plant spacing $\left(20.4 \mathrm{t} \cdot \mathrm{ha}^{-1}\right)$, intermediate with $30-\mathrm{cm}$ spacing $\left(18.0 \mathrm{t} \cdot \mathrm{ha}^{-1}\right)$, and lowest with $38-\mathrm{cm}$ spacing $\left(17.0 \mathrm{t} \cdot \mathrm{ha}^{-1}\right)$. In contrast, the greatest number of storage roots per plant was produced with $38-\mathrm{cm}$ plant spacing (3.4). There were more jumbo sweetpotatoes produced with PE mulch $\left(3.4 \mathrm{t} \cdot \mathrm{ha}^{-1}\right)$ and with $30-\mathrm{cm}$ spacing (3 $\left.\mathrm{t} \cdot \mathrm{ha}^{-1}\right)$, and the weight of U.S. No. 2 grade sweetpotatoes was greatest at $20-\mathrm{cm}$ spacing $\left(10.2 \mathrm{t} \cdot \mathrm{ha}^{-1}\right)$. Soil temperature was increased by $3^{\circ} \mathrm{C}$ under the PE mulch and $2{ }^{\circ} \mathrm{C}$ under the BDM compared with bare ground. However, $98 \%$ of storage roots were observed to be severely damaged by wireworm in 2019 , with more than 10 to 20 holes per storage root. For wireworm-resistant accessions in $2020,16 \%$ of the storage roots were damaged by wireworm, with 1.7 to 4.0 holes per storage root. Total yield of accessions PI 666141 and 04-791 (45.5 $\mathrm{t} \cdot \mathrm{ha}^{-1}$ on average) was greater than the national average $\left(24.7 \mathrm{t} \cdot \mathrm{ha}^{-1}\right)$. Overall, sweetpotatoes appear to be suitable for production in northwest Washington, but low yield in 2019 highlights the importance of healthy slips for successful production. Future research should evaluate cultivars with maximum adaptation to the region, techniques to reduce wireworm damage including genetic resistance, and the economics of producing sweetpotatoes in northern regions.

S weetpotato (Ipomoea batatas) is one of the most nutritious root crops, and ranks seventh in world food production after wheat

Received for publication 12 Nov. 2021. Accepted for publication 24 Jan. 2022.

Published online 25 February 2022.

${ }^{1}$ Department of Horticulture, Washington State University, Northwestern Washington Research and Extension Center, 16650 State Route 536, Mount Vernon, WA 98273

Funding support was provided by U.S. Department of Agriculture, National Institute of Food and Agriculture Hatch Project 1017286. Technical assistance was provided by Ed Scheenstra.

C.M. is the corresponding author. E-mail: milesc@ wsu.edu.

This is an open access article distributed under the CC BY-NC-ND license (https://creativecommons. org/licenses/by-nc-nd/4.0/).

https://doi.org/10.21273/HORTTECH04992-21
(Triticum aestivum), rice (Oryza sativa), maize (Zea mays), potato (Solanum tuberosum), barley (Hordeum vulgare), and cassava (Manibot esculenta) (Brandenberger et al., 2014;
Food and Agriculture Organization of the United Nations, 2019; Johnson et al., 2015; Truong et al., 2018). In the United States, the national average yield of sweetpotato in 2018 was 11 tons/acre $\left(24.7 \mathrm{t} \cdot \mathrm{ha}^{-1}\right)$ [U.S. Department of Agriculture (USDA), National Agricultural Statistics Service (NASS), 2020] and per capita annual consumption was $6.7 \mathrm{lb}$ in 2015. Commercial production of sweetpotato is concentrated in the warmer states, with North Carolina, Louisiana, California, Arkansas, Florida, and Mississippi accounting for $94 \%$ of total production in 2018 (USDA, NASS, 2020). Sweetpotato has not been grown commercially in the northern United States because of the perceived limitations of a short growing season and relatively cool summer temperatures. However, PE mulch has been used successfully to increase soil temperatures and productivity for many crops including sweetpotato (Duque, 2020; Sideman, 2015; Wees et al., 2015, 2016). In a cultivar trial in Pennsylvania where all the entries were grown with black PE mulch, the total marketable yields of the highest-yielding sweetpotato cultivars ranged from 548 to $70650-\mathrm{lb}$ bushels/acre (30.7 to $39.6 \mathrm{t} \cdot \mathrm{ha}^{-1}$ ) (Duque, 2020). In another cultivar trial grown with black PE mulch in the cool climate and short growing season of Quebec, Canada, Wees et al. (2016) reported sweetpotato marketable yields of $24.4 \mathrm{t} \cdot \mathrm{ha}^{-1}$. Similarly, in a sweetpotato cultivar trial grown with black BDM in New Hampshire, the highestyielding cultivars included Covington and Beauregard that produced marketable yields ranging from 503 to 887 50-lb bushels/acre (28.2 to 49.7 $\mathrm{t} \cdot \mathrm{ha}^{-1}$ ) (Sideman, 2015). The sweetpotato yields in that study were $17 \%$ to $108 \%$ greater than the national average. These studies suggest that 
sweetpotatoes may be grown successfully with black plastic mulch in northwest Washington, which has a warm Mediterranean climate (Peel et al., 2007 ) with an average soil temperature of $18^{\circ} \mathrm{C}$ at $20-\mathrm{cm}$ depth during the summer (June through September) growing season [10-year average (AgWeatherNet, 2020)].

An alternative to $\mathrm{PE}$ mulch is desired to reduce agricultural plastic waste, and BDM is suitable as it provides comparable crop production benefits and can be tilled into the soil after use, where it will biodegrade (Cowan et al., 2014; Ghimire et al., 2018; Tofanelli and Wortman, 2020). In studies with pie pumpkin (Cucurbita pepo) in northwest Washington, Sintim et al. (2019) reported that soil temperatures at 10 - and $20-\mathrm{cm}$ depths were 1 to $5^{\circ} \mathrm{C}$ greater under black plastic BDMs and PE mulch compared with no-mulch early in the growing season, when the plant canopy had not fully developed. In two studies with pumpkin at the same location, black plastic BDMs and PE mulch increased the soil temperature by 1 to $1.8^{\circ} \mathrm{C}$ at a $10-\mathrm{cm}$ depth compared with no-mulch, and the soil temperature was $0.5^{\circ} \mathrm{C}$ higher under black PE mulch than under black BDM (Ghimire et al., 2018; Zhang et al., 2020). Waterer (2010) reported no significant differences in soil temperature and crop yield for clear, black, and wavelength-selective PE mulches (BioWay, Leduc, AB, Canada) and BDMs (DuBois Agrinovation, St. Remi, QC, Canada) in Saskatchewan, Canada. In that study, 'Navajo' sweet corn $(Z$. mays), 'Goldrush' zucchini (C. pepo), 'Fastbreak' cantaloupe (Cucumis melo), 'Redstart' pepper (Capsicum annumm), and 'Dusky' eggplant (Solanum melongena) had similar production across all treatments for three cropping seasons. For tomato (Solanum lycopersicum), similar yields were observed when grown with black PE mulch and BDM in Spain and the United States (Anzalone et al., 2010; Cowan et al., 2014; Martin-Closas et al., 2008; Moreno and Moreno, 2008).

Sweetpotato plant growth (i.e., number and length of vines) and root yield (i.e., size, number, and weight) are also strongly influenced by planting density, and optimal spacing can differ based on location (Onunka et al., 2011). The most common plant spacing for sweetpotato in North Carolina

is 20 to $36 \mathrm{~cm}$ within-row and 91 to $122 \mathrm{~cm}$ between-row (Jennings et al., 2019). In Kentucky, the recommended plant spacing is 25 to $36 \mathrm{~cm}$ inrow and 91 to $122 \mathrm{~cm}$ between-row, whereas in Ontario the recommended plant spacing is 30 to $40 \mathrm{~cm}$ in-row and 102 to $112 \mathrm{~cm}$ between-row [Coolong et al., 2012; Ontario Ministry of Agriculture, Food and Rural Affairs (OMAFRA), 2012]. These plant spacings provide planting densities of $\approx 22,000$ to 55,000 plants/ha. Further, as in-row spacing was increased, the total root yield decreased but the yield of jumbosized roots increased, which can be desirable for some markets (Anderson et al., 1945). The plant spacing to achieve maximum root yield and size appears to increase as the production moves farther north and may be cultivar dependent; thus, studies are needed to determine optimal plant spacing for each region.

Potential pest issues are another consideration for sweetpotato production in each region. The major soildwelling insect pests reported to affect sweetpotatoes in the United States are beetles (Coleoptera), including the spotted cucumber beetle (Diabrotica undecimpunctata), banded cucumber beetle (Diabrotica balteata), sweetpotato flea beetle (Chaetocnema confinis), elongate flea beetle (Systena elongata), wireworm larvae (Conoderus sp.), white grub larvae (Phyllophaga sp. and Plectris aliena), sugarcane beetle (Euetheola rugicepes), and sweetpotato weevil (Cylas formicarius) (Cuthbert, 1967; Smith, 2006; Sorensen, 2009). Sweetpotato weevils and wireworms are reported as the most damaging insect pests worldwide, and of all reported beetle pests, only Agriotes and Limonius species of wireworm have been reported in northwest Washington (Seal et al., 2020).

The overall goal of this study was to ascertain if sweetpotato could be suitable for production in northwest Washington. Specific objectives were to 1) compare the impacts of $\mathrm{PE}$ mulch and BDM and different in-row spacings on productivity in northwest Washington, and 2) identify potential pest threats of sweetpotato production in this region and evaluate resistant accessions to manage the pest problem.

\section{Materials and methods}

Experimental LOCATION. This study was carried out at Washington State University (WSU) Northwestern Washington Research and Extension Center, Mount Vernon (lat. $48^{\circ} 43^{\prime} 24^{\prime \prime}$ $\mathrm{N}$, long. $122^{\circ} 39^{\prime} 09^{\prime \prime} \mathrm{W}$; elevation $6 \mathrm{~m}$ ) in the Pacific Northwest in 2019 and 2020. The region has a warm Mediterranean climate, and during the summer growing season (June through September) average air temperature is $15^{\circ} \mathrm{C}$ (average maximum $21^{\circ} \mathrm{C}$ and average minimum $10.5^{\circ} \mathrm{C}$ ), precipitation is 170 $\mathrm{mm}$, and relative humidity $(\mathrm{RH})$ is 80\% [20-year average (AgWeatherNet, 2020)]. The experimental site has a Skagit silt loam soil with a $\mathrm{pH}$ of 6.4 and 2.7\% organic matter (USDA, Natural Resource Conservation Service, 1960).

2019 FIELD EXPERIMENT. The objective of this experiment was to compare the impacts of PE mulch and BDM and different in-row spacings on sweetpotato productivity. The experiment had a randomized complete split plot design with two main plot treatments, three subplot treatments, and four replications (Fig. 1). The main plot treatment was mulch with black BDM (0.7 mil, $4 \mathrm{ft}$ wide; Organix Solutions, Grove, $\mathrm{MN}$ ) and black PE mulch (1 mil, $4 \mathrm{ft}$ wide; Filmtech, Allentown, PA). The subplot treatment was in-row plant spacing at 20,30 , and $38 \mathrm{~cm}$, which were selected from the range of common sweetpotato in-row spacings (Coolong et al., 2012; Jennings et al., 2019; OMAFRA, 2012). Each subplot was $15 \mathrm{ft}$ long. Subplots with $20-\mathrm{cm}$ in-row spacing had 22 plants/ plot, $30-\mathrm{cm}$ in-row spacing had 15 plants, and $38-\mathrm{cm}$ in-row spacing had 11 plants. A nonreplicated single nomulch reference plot with in-row spacing of $38 \mathrm{~cm}$ also was included.

Fertilizer (16N-7P-13K; WilburEllis, San Francisco, CA) was applied to the center of the row at the rate of $100 \mathrm{lb} /$ acre of nitrogen with a 6-ft drop-spreader (Gandy, Owatonna, $\mathrm{MN}$ ) just before the beds were formed 1 week before planting. Raised beds were 15 to $20 \mathrm{~cm}$ high and $0.8 \mathrm{~m}$ wide, spaced $3 \mathrm{~m}$ center-to-center. Beds were spaced wide apart to allow for mechanical cultivation of weeds early in the season. Drip irrigation tape [ $8 \mathrm{mil}, 8$-inch emitter spacing, $0.34 \mathrm{gal} / \mathrm{min}$ per 100 ft flowrate (T-Tape model 508-08-340; 


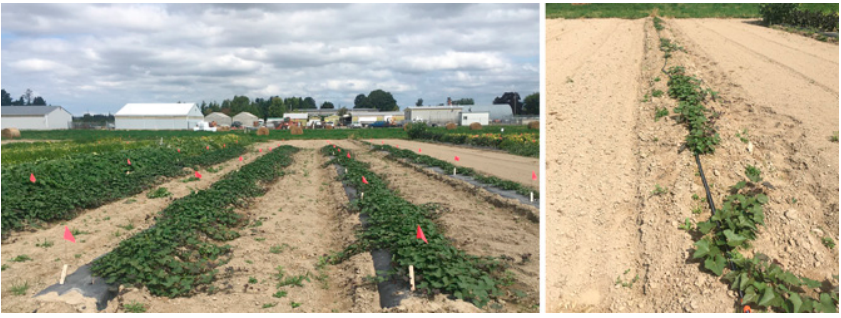

Fig. 1. 'Covington' sweetpotato grown with polyethylene (PE) and soilbiodegradable plastic mulch (BDM) at three plant spacings $(20,30$, and $38 \mathrm{~cm})$ (left) and without mulch as a nonreplicated reference plot at $38-\mathrm{cm}$ plant spacing (right) at Washington State University Northwestern Washington Research and Extension Center, Mount Vernon, WA, on 19 Aug. $2019 ; 1 \mathrm{~cm}=0.3937$ inch.

Rivulis, San Diego, CA)] was laid during bed shaping simultaneously with mulch.

Slips of 'Covington' sweetpotato (Jones Family Farm, Bailey, NC) arrived on 7 June 2019 and were transplanted on the same day. Slips took $1 \mathrm{~d}$ longer in shipping than arranged ( $4 \mathrm{~d}$ rather than $3 \mathrm{~d}$ ) and were in very poor health on arrival, which negatively affected survival and establishment in the field. Remaining slips were placed in shallow plastic bulb crates with moist potting mix (Sunshine \#3 N\&O; Sun Gro Horticulture, Agawam, MA) in a shaded high tunnel and were used to replace dead plants in the field. Many slips (60\% to $70 \%)$ did not survive the first transplanting and were replaced throughout the field experiment on 10 and 17 June. Weeds were managed in the alleyways by rototilling, and bed edges, planting holes, and the nomulch reference plot were handweeded as needed throughout the growing season. No pesticides were applied to the experiment so that any potential pest issues could be observed.

2020 FIELD EXPERIMENT. The objective of this experiment was to evaluate wireworm-resistant accessions, as only this pest severely affected the 2019 experiment. On 11 Feb. 2020, eight wireworm-resistant sweetpotato accessions (PI 666139, PI 666141, W382, W388, 04-136, 04-284, 04791, and 09-130) were received from the USDA, Agricultural Research Service (P.A. Wadl) (Table 1 ). Plant material arrived as tissue culture plantlets, and on arrival were washed and transplanted into sterilized 4-inch pots filled with autoclaved potting mix (same product as in 2019) that was lightly moistened. Pots were placed in a humidity box in the greenhouse, the plants and inside of the box were sweetpotatoes were grown in 2019. Vernon, WA, in 2020 . $^{\mathrm{z}}$

${ }^{\mathrm{x}}$ Accession did not survive in the greenhouse. slightly misted before closing the box, and the box was covered with shade cloth to maintain $50 \%$ to $70 \%$ light. The environment within the box was maintained at 25 to $27^{\circ} \mathrm{C}$ and $80 \%$ to $85 \% \mathrm{RH}$. The shade cloth cover was removed from one side of the box on the third day, from two sides of the box on the fourth day, and from three sides on the fifth day. On the sixth day, the cloth was completely removed, and the plants were placed on the greenhouse bench. Two of the accessions, PI 666139 and W388, did not survive. The remaining six accessions were propagated by vine cuttings in the greenhouse. On 8 June, the plants were placed in the same field where

Fertilizer (same product as in 2019) was applied at the rate of 100 $\mathrm{lb} /$ acre of nitrogen and beds were formed following the same procedures as in 2019. Beds were mulched with BDM (same product as in 2019) and spacing between plants was 38 $\mathrm{cm}$ based on 2019 results to provide the maximum number of storage roots per plant to assess wireworm

incidence. The experiment included a single plot of each accession due to low plant numbers and the number of plants per accession varied due to propagation differences. Field data that were collected in 2019 were not collected in 2020 because of limited ability to carry out research experiments during the Coronavirus Disease 2019 (COVID-19) pandemic.

Weather Data. Air temperature, $\mathrm{RH}$, solar radiation, and rainfall data during the cropping season of both years were collected from the WSU AgWeatherNet station (AgWeatherNet, 2020) located $\approx 140 \mathrm{~m}$ from the experimental field plots. Soil temperature was measured every $15 \mathrm{~min}$ using data loggers (HOBO; Onset Computer Corp., Bourne, MA). A temperature probe (S-TMB-M002; Onset Computer Corp.) was placed at a $10-\mathrm{cm}$ depth under the plastic mulch in the center of both main plots in the second replicate and in the center of the no-mulch reference plot in 2019, and under the BDM in the center of the third plot in 2020.

Mulch DETERIORATION. In 2019, mulch deterioration was measured visually during the crop growing season in the center $1 \mathrm{~m}$ of each plot at the beginning of each month from July through September. Mulch deterioration was assessed as percent soil exposure (PSE) where 0\% represents completely intact mulch and $100 \%$ represents fully exposed soil (Cowan et al., 2014). Ratings were done in $1 \%$ increments until $20 \%$ exposure, and $5 \%$ increments thereafter. The PSE region was visualized in a grid of $100(10 \times 10)$ boxes, and the mulch deterioration in the grid was noted. Further, visual rating of mulch

Table 1. Number of sweetpotato plantlets per accession, number of plants transplanted per accession per plot, and length of each plot at Washington State University Northwestern Washington Research and Extension Center, Mount

\begin{tabular}{lccc}
\hline Accession no. & Plantlets (no.) & Plants (no./plot) & Plot length $(\mathbf{f t})^{\mathbf{y}}$ \\
\hline PI 666139 & 1 & $-{ }^{\mathrm{x}}$ & - \\
PI 666141 & 1 & 18 & 23 \\
W382 & 1 & 35 & 44 \\
W388 & 1 & - & - \\
$04-136$ & 2 & 11 & 14 \\
$04-284$ & 2 & 20 & 25 \\
$04-791$ & 1 & 13 & 16 \\
$09-130$ & 2 & 28 & 35
\end{tabular}

${ }^{\mathrm{z}}$ Plants obtained from the U.S. Department of Agriculture, Agricultural Research Service (P.A. Wadl).

${ }^{\mathrm{y}}$ Plants were transplanted at $38-\mathrm{cm}(15.0$ inches $)$ in-row spacing; $1 \mathrm{ft}=0.3048 \mathrm{~m}$. 
deterioration is subjective, and the same person was responsible for this data collection throughout the experiment to maintain consistency.

Plant establishment and GROWTH. In 2019, plant establishment was measured as the total number of live plants per plot and was recorded at 3 weeks (27 June) and 7 weeks (25 July) after transplanting. The length of the longest vine was measured from the base to the tip of the vine for the center six plants in each plot at 7 weeks (25 July) and 11 weeks (22 Aug.) after transplanting. Percent canopy cover was measured on 30 July and then twice per month until 10 Sept. using digital photographs and a green canopy cover measurement tool (Canopeo version 2.0; Canopeo, Stillwater, OK) developed by the Soil Physics Research Group at Oklahoma State University (Patrignani and Ochsner, 2015) (Fig. 2). Photographs were taken at a $1-\mathrm{m}$ height centered above the central plant in each plot, and included an area $\approx 130 \mathrm{~cm}$ long and $75 \mathrm{~cm}$ wide. Beds were hand-weeded before each measurement so that no weeds were in the images. Canopy cover was calculated as the percentage of foliage in the image.

YIELD AND WIREWORM DAMAGE. In 2019, sweetpotato roots were harvested on 9 and 10 Oct., and in 2020 harvest was on 7 Oct. In both years, harvest was before the soil temperature was below $13^{\circ} \mathrm{C}$ to maintain storability of the roots (Brandenberger et al., 2014). Vines were cut and removed from all plots the day before harvest each year to prevent interference with harvesting, and PE mulch was removed from all respective plots. The center $6 \mathrm{ft}$ of each plot in 2019 and the center $5 \mathrm{ft}$ of each plot in 2020 was hand harvested for yield and wireworm damage measurements. The remaining area of each plot was harvested using a single-row potato digger (model D-10M; U.S. Small Farm Equipment Co., Worland, WY).

In 2019, total root weight and marketable root weight per hectare and number of storage roots per plant were calculated for each plot; marketable yield was based on storage roots that had shape and size that would have been considered marketable if they were not damaged by wireworm.
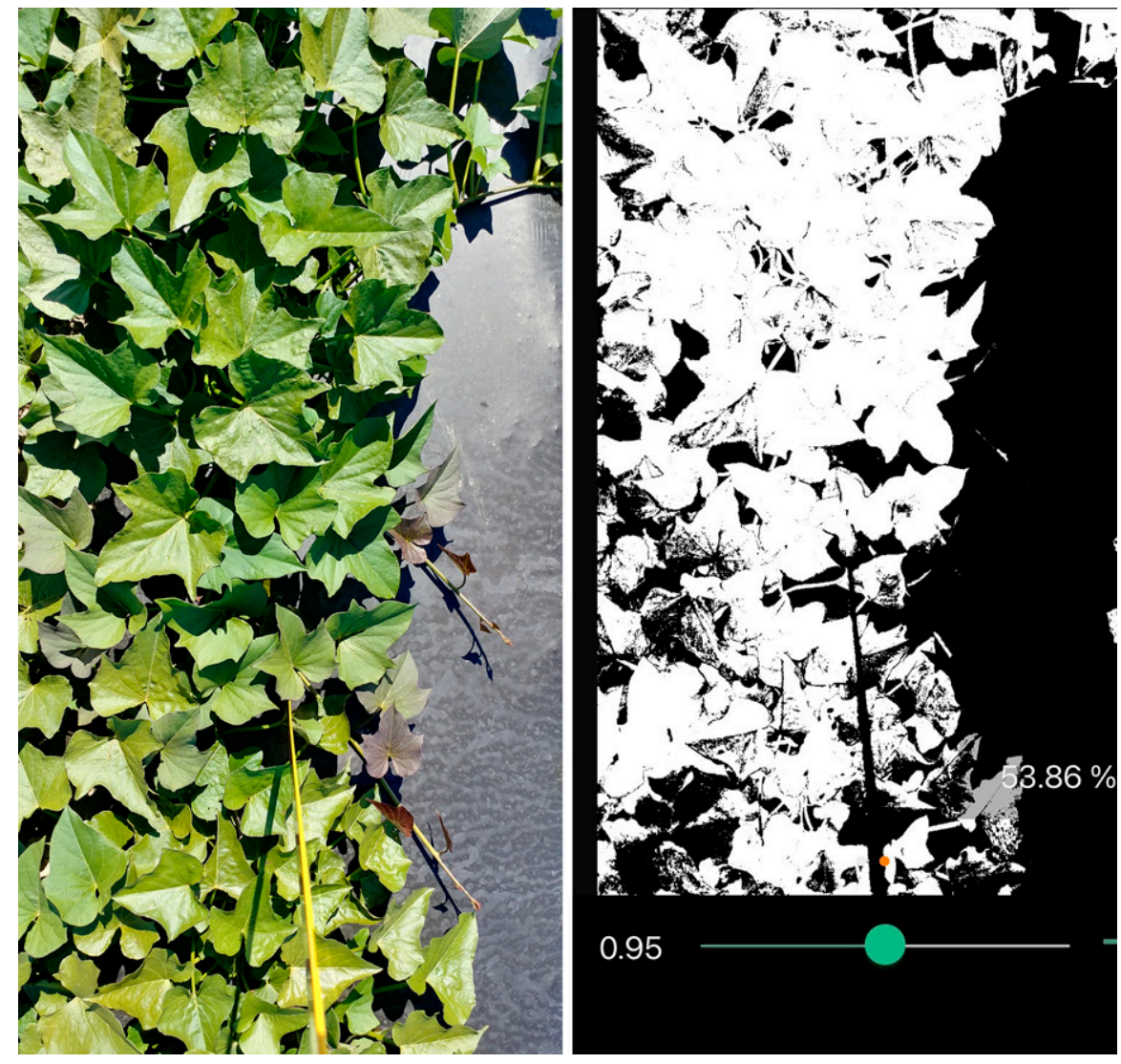

Fig. 2. Measurement of percent canopy cover of 'Covington' sweetpotato grown with polyethylene (PE) and soil-biodegradable plastic mulch (BDM) at three plant spacings $(20,30$, and $38 \mathrm{~cm})$ using digital photographs and a green canopy cover measurement tool (Canopeo version 2.0; Canopeo, Stillwater, OK) at Washington State University Northwestern Washington Research and Extension Center, Mount Vernon, WA, on 30 July 2019; $1 \mathrm{~cm}=0.3937$ inch.

Sweetpotatoes were then sorted into size categories, and total root weight in each grading category was calculated per plot. Grading followed U.S. standards for grades of sweetpotatoes (USDA, Agricultural Marketing Service, 2005): Jumbo ( $>9$ inches length and $>3.5$ inches diameter $)$, U.S. No. 1 (3-9 inches length and 1.75-3.5 inches diameter), U.S. No. 2 ( $\geq 1.5$ inches diameter), and cull (storage roots of any size with off-shapes). Sweetpotatoes were not sorted into categories in 2020 because of work restrictions caused by the COVID-19 pandemic, and only total root number and weight were measured for each plot and yield per hectare was calculated.

Yield per hectare in both years was calculated based on the mean yield per plant for each treatment (which took into account reduced plant stand) by multiplying with a correction factor of 1.7 to convert the wide row-to-row spacing of $3 \mathrm{~m}$ that was used in this study to $6-\mathrm{ft}$ spacing that is common for commercial production using mulched beds. In both years, the percentage of sweetpotato roots that had one or more holes indicative of wireworm damage was calculated for each plot, and in 2020 the number of holes caused by wireworm damage per storage root was recorded for each plot.

Data analysis. All data were analyzed using statistical analysis software ( $\mathrm{R}$ version 1.4.1106-5 for Windows; RStudio, Boston, MA; SAS version 9.4 for Windows; SAS Institute, Cary, NC). The assumptions of normality and homogeneity of variance were tested using the ShapiroWilk test $(\alpha=0.05)$ and the Levene's test $(\alpha=0.05)$, respectively, and the data were subjected to analysis of variance. A nonparametric transformation was applied using PROC RANK in SAS to the data that did not satisfy the assumptions of normality with any transformation. All means presented are nontransformed, and means were 
separated using Tukey's honestly significant difference at a significance level of $\alpha<0.05$.

\section{Results}

ENVIRONMENTAL AND SOIL CONDITIONS. During the growing season both years (June through September), the average air temperature was $16^{\circ} \mathrm{C}$ (range 5 to $21^{\circ} \mathrm{C}$ in 2019 and 11 to $22^{\circ} \mathrm{C}$ in 2020) (Table 2). The average minimum air temperature was $11^{\circ} \mathrm{C}$ in both years (range -1 to $17^{\circ} \mathrm{C}$ in 2019 and 9 to $16^{\circ} \mathrm{C}$ in 2020 ), and average maximum air temperature was $21^{\circ} \mathrm{C}$ for 2019 (range 11 to $30^{\circ} \mathrm{C}$ ) and $22^{\circ} \mathrm{C}$ for 2020 (range 14 to $32^{\circ} \mathrm{C}$ ). Average daily $\mathrm{RH}$ was $61 \%$ in 2019 (range $3 \%$ to $91 \%$ ) and $79 \%$ in 2020 (range $56 \%$ to 98\%). Overall, 2019 had $80 \%$ greater precipitation and $34 \%$ lower total solar radiation $\left(229 \mathrm{~mm}\right.$ and $1434 \mathrm{MJ} \cdot \mathrm{m}^{-2}$, respectively) than 2020 (127 $\mathrm{mm}$ and $2175 \mathrm{MJ} \cdot \mathrm{m}^{-2}$, respectively). Average soil temperature at $10-\mathrm{cm}$ depth in 2019 was greatest under PE mulch $\left[21^{\circ} \mathrm{C}\right.$ (range 8 to $31^{\circ} \mathrm{C}$ )], intermediate under $\mathrm{BDM}\left[20^{\circ} \mathrm{C}\right.$ (range 7 to $\left.\left.26^{\circ} \mathrm{C}\right)\right]$, and lowest in no-mulch $\left[18^{\circ} \mathrm{C}\right.$ (range 7 to $27^{\circ} \mathrm{C}$ )]. In 2020 , the average soil temperature under $\mathrm{BDM}$ at $10-\mathrm{cm}$ depth was also $20^{\circ} \mathrm{C}$ (range 13 to $28^{\circ} \mathrm{C}$ ).

Percent SOIL EXPosure. In July, Aug., and Sept. 2019, PSE differed due to mulch $(P \leq 0.0003$ for all) but not due to plant spacing $(P \geq$ 0.48 for all) (Table 3 ), and there was no interaction between mulch and plant spacing $(P=0.54, P=0.29$, and $P=0.30$, respectively). PSE remained constant over time for $\mathrm{PE}$ mulch $(0.4 \%)$ but increased for BDM, and was $\approx 2 \%$ in July and August, and $11 \%$ in September.

Plant establishment and GROWTH. Average plant stand in 2019 was $68 \%$ at week 3 after transplanting and $76 \%$ at week 7 after transplanting, and did not differ due to mulch $(P=$ 0.26 and $P=0.40$, respectively) or plant spacing $(P=0.58$ and $P=0.26$, respectively) (Table 4 ). There also was no interaction between mulch and plant spacing (week $3 P=0.61$, week $7 P=0.08)$. In the no-mulch reference plot, plant stand was $28 \%$ less on average than with mulch at 3 and 7 weeks after transplanting $(49 \%$ and $55 \%$, respectively). At week 3 after transplanting, some plants were defoliated
Table 2. Environmental and soil conditions during the growing season (7 June to 10 Oct. 2019 and 8 June to 7 Oct. 2020) at Washington State University Northwestern Washington Research and Extension Center, Mount Vernon, WA, in 2019 and $2020 .^{\mathrm{z}}$

\begin{tabular}{|c|c|c|}
\hline Environmental variables $^{\mathrm{y}}$ & 2019 & 2020 \\
\hline Average daily air temperature $\left({ }^{\circ} \mathrm{C}\right)$ & 16 & 16 \\
\hline Average daily maximum air temperature $\left({ }^{\circ} \mathrm{C}\right)$ & 21 & 22 \\
\hline Average daily minimum air temperature $\left({ }^{\circ} \mathrm{C}\right)$ & 11 & 11 \\
\hline Total solar radiation $\left(\mathrm{MJ} \cdot \mathrm{m}^{-2}\right)$ & 1434 & 2175 \\
\hline Relative humidity (\%) & 61 & 79 \\
\hline Total rainfall $(\mathrm{mm})$ & 229 & 127 \\
\hline \multicolumn{3}{|l|}{ Soil temperature $\left({ }^{\circ} \mathrm{C}\right)^{\mathrm{x}}$} \\
\hline Polyethylene mulch ${ }^{w}$ & 21 & $-{ }^{\mathrm{v}}$ \\
\hline Soil-biodegradable plastic mulch & 20 & 20 \\
\hline No-mulch & 18 & - \\
\hline \multicolumn{3}{|c|}{ 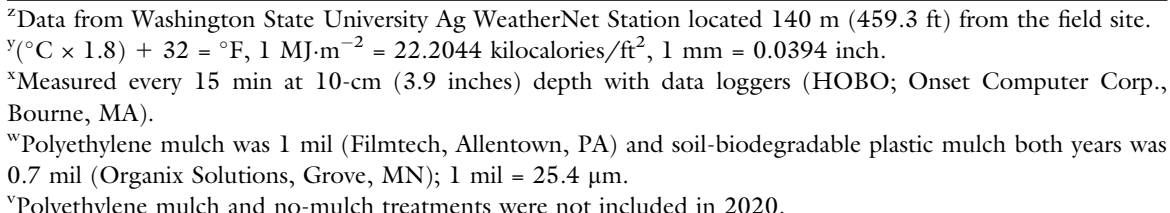 } \\
\hline
\end{tabular}

and appeared necrotic, and hence were counted as dead. However, after a few weeks, these plants resprouted from below-ground causing an increase in the recorded plant stand.

Average length of the longest vine was $20 \mathrm{~cm}$ at week 7 after transplanting, and $113 \mathrm{~cm}$ at week 11 after transplanting, and did not differ due to mulch $(P=0.32$ and $P=0.68$, respectively) or plant spacing $(P=$ 0.28 and $P=0.60$, respectively) (Table 4). The length of the longest vine in the no-mulch reference bed was $60 \%$ and $29 \%$ less at 7 and 11 weeks after transplanting, respectively, when compared with the mulched beds. There was an interaction between mulch and plant spacing for vine length at week $7(P=0.03)$ but not at week $11(P=0.31)$. At week 7 , vine length was greatest with $\mathrm{PE}$ mulch at $38-\mathrm{cm}$ spacing $(24.7 \mathrm{~cm})$ (data not presented).

Canopy cover did not differ due to mulch at any measurement time after transplanting in 2019 (Table 4) and was $19 \%$ at week $8(P=0.88)$, $51 \%$ at week $10(P=0.66), 60 \%$ at week $12(P=0.84)$, and $83 \%$ at week 14 after transplanting $(P=0.34)$. In the no-mulch reference plot, canopy cover was $73 \%, 65 \%, 32 \%$, and $24 \%$
Table 3. Mulch deterioration measured as percent soil exposure (PSE) once per month in the center $1 \mathrm{~m}(3.3 \mathrm{ft})$ of each plot of 'Covington' sweetpotato grown with polyethylene (PE) and soil-biodegradable plastic mulch (BDM) at different plant spacings $(20,30$, and $38 \mathrm{~cm})$ at Washington State University Northwestern Washington Research and Extension Center, Mount Vernon, WA, in 2019.

\begin{tabular}{lllc}
\hline & \multicolumn{3}{c}{ PSE (\%) $)^{\mathbf{z}}$} \\
\cline { 2 - 4 } Treatment & July & August & September \\
\hline Mulch $^{\mathrm{y}}$ & & & \\
PE mulch & 0.4 & 0.4 & 0.4 \\
BDM & 2.0 & 2.6 & 11.0 \\
P value & 0.0003 & $<0.0001$ & $<0.0001$
\end{tabular}

Spacing $(\mathrm{cm})^{\mathrm{x}}$

$\begin{array}{llll}20 & 1.6 & 1.8 & 5.8 \\ 30 & 1.3 & 1.4 & 5.4 \\ 38 & 0.9 & 1.4 & 6.0 \\ P \text { value } & 0.48 & 0.97 & 0.87\end{array}$

${ }^{\mathrm{z}} 0 \%$ PSE denoted mulch that was completely intact, and $100 \%$ PSE denoted fully deteriorated mulch. Ratings were in $1 \%$ increments up to $20 \%$ PSE, and in $5 \%$ increments thereafter.

${ }^{\mathrm{y}} \mathrm{PE}$ mulch was $1 \mathrm{mil}$ (Filmtech, Allentown, PA) and BDM was 0.7 mil (Organix Solutions, Grove, MN); $1 \mathrm{mil}$ $=25.4 \mu \mathrm{m}$.

${ }^{\mathrm{x}} 1 \mathrm{~cm}=0.3937$ inch. 
Table 4. Average plant stand, longest vine length, and canopy cover of 'Covington' sweetpotato grown with polyethylene (PE) and soil-biodegradable plastic mulch (BDM) at three plant spacings $(20,30$, and $38 \mathrm{~cm})$ at Washington State University Northwestern Washington Research and Extension Center, Mount Vernon, WA, in 2019.

\begin{tabular}{|c|c|c|c|c|c|c|c|c|}
\hline \multirow[b]{2}{*}{ Treatment } & \multicolumn{2}{|c|}{ Plant stand (\%) } & \multicolumn{2}{|c|}{ Longest vine length $(\mathrm{cm})^{\mathrm{z}}$} & \multicolumn{4}{|c|}{ Canopy cover (\%) } \\
\hline & $3 \mathrm{WAT}^{\mathrm{y}}$ & 7 WAT & 7 WAT & $11 \mathrm{WAT}$ & 8 WAT & $10 \mathrm{WAT}$ & $12 \mathrm{WAT}$ & 14 WAT \\
\hline \multicolumn{9}{|l|}{ Mulch $^{\mathrm{x}}$} \\
\hline PE mulch & $73^{w}$ & 79 & 22 & 116 & 19 & 53 & 61 & 84 \\
\hline BDM & 63 & 72 & 18 & 110 & 18 & 49 & 59 & 82 \\
\hline$P$ value & 0.26 & 0.40 & 0.32 & 0.68 & 0.88 & 0.66 & 0.84 & 0.34 \\
\hline \multicolumn{9}{|l|}{ Spacing $(\mathrm{cm})^{\mathrm{z}}$} \\
\hline 20 & 73 & 80 & 22 & 120 & 23 & 59 & $67 a^{v}$ & $89 a$ \\
\hline 30 & 61 & 70 & 18 & 109 & 16 & 47 & $54 \mathrm{~b}$ & $79 \mathrm{~b}$ \\
\hline 38 & 70 & 77 & 19 & 110 & 16 & 47 & $58 \mathrm{ab}$ & $82 \mathrm{ab}$ \\
\hline$P$ value & 0.58 & 0.26 & 0.28 & 0.60 & 0.09 & 0.06 & 0.03 & 0.004 \\
\hline No-mulch ${ }^{\mathrm{u}}$ & 49 & 55 & 8 & 80 & 5 & 18 & 41 & 63 \\
\hline \multicolumn{9}{|c|}{ 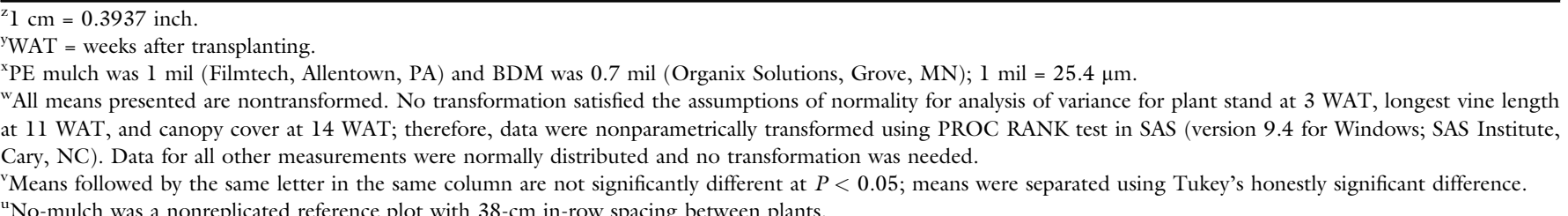 } \\
\hline
\end{tabular}

less than with mulch at weeks 8,10 , 12, and 14 after transplanting, respectively. Percent canopy cover did not differ due to plant spacing at weeks 8 and 10 after transplanting ( $P=0.09$ and $P=0.06$, respectively); however, there was a difference at weeks 12 and 14 after transplanting $(P=0.03$ and $P=0.004$, respectively) when canopy cover was greater for $20-\mathrm{cm}$ spacing than 30 - $\mathrm{cm}$ spacing and intermediate for $38-\mathrm{cm}$ spacing (Table 4 ). There was no interaction between mulch and plant spacing at weeks $8(P=0.19)$, $10(P=0.12)$, and $12(P=0.15)$ after transplanting, but there was an interaction at week 14 after transplanting $(P=0.01)$. At week 14 , the greatest canopy cover (90\%) was with PE mulch at 38- $\mathrm{cm}$ spacing (data not presented).
YIELD AND WIREWORM DAMAGE. In 2019, total storage root yield was $22 \mathrm{t} \cdot \mathrm{ha}^{-1}$ with PE mulch and $15 \mathrm{t} \cdot \mathrm{ha}^{-1}$ with $\operatorname{BDM}(P=0.06)$ (Table 5). Although not statistically different due to variability among plots, there was a $47 \%$ difference between yield with PE mulch and BDM. There was a difference in total root yield due to plant spacing $(P=0.03)$ and $20-\mathrm{cm}$ spacing had the greatest total yield

Table 5. Total yield, marketable yield, storage root number per plant, jumbo yield, U.S. No. 1, U.S. No. 2, and number of storage roots with wireworm damage of 'Covington' sweetpotato grown with polyethylene (PE) and soil-biodegradable plastic mulch (BDM) at different plant spacings $(20,30$, and $38 \mathrm{~cm})$ at Washington State University Northwestern Washington Research and Extension Center, Mount Vernon, WA, in 2019. ${ }^{\mathrm{z}}$

\begin{tabular}{|c|c|c|c|c|c|c|c|}
\hline Treatment & $\begin{array}{l}\text { Total yield } \\
\left(\mathrm{t} \cdot \mathrm{ha}^{-1}\right)^{\mathrm{y}}\end{array}$ & $\begin{array}{c}\text { Marketable } \\
\text { yield }\left(t \cdot h^{-1}\right)\end{array}$ & $\begin{array}{l}\text { Storage roots } \\
\text { (no./plant) }\end{array}$ & $\underset{\left(t \cdot h a^{-1}\right)^{x}}{\text { Jumbo }}$ & $\begin{array}{l}\text { U.S. No. I } \\
\left(\mathrm{t} \cdot \mathrm{ha}^{-1}\right)^{\mathrm{x}}\end{array}$ & $\begin{array}{l}\text { U.S. No. } 2 \\
\left(\mathrm{t} \cdot \mathrm{ha}^{-1}\right)^{\mathrm{x}}\end{array}$ & $\begin{array}{c}\text { Wireworm } \\
\text { damage }(\%)\end{array}$ \\
\hline \multicolumn{8}{|l|}{ Mulch $^{w}$} \\
\hline $\mathrm{BDM}$ & 15.0 & 10.7 & 2.6 & 0.5 & 3.2 & 7.0 & 97 \\
\hline$P$ value & 0.06 & 0.06 & 0.18 & 0.004 & 0.30 & 0.39 & 0.80 \\
\hline \multicolumn{8}{|l|}{ Spacing $(\mathrm{cm})^{\mathrm{v}}$} \\
\hline 38 & $17.0 \mathrm{~b}$ & 12.8 & $3.4 \mathrm{a}$ & $2.5 \mathrm{ab}$ & 4.1 & $6.1 \mathrm{~b}$ & 98 \\
\hline$P$ value & 0.03 & 0.25 & 0.006 & 0.04 & 0.64 & 0.008 & 0.38 \\
\hline No-mulch $^{t}$ & 5.8 & 2.9 & 1.2 & 0 & 0 & 2.8 & $100 \%$ \\
\hline \multicolumn{8}{|c|}{ 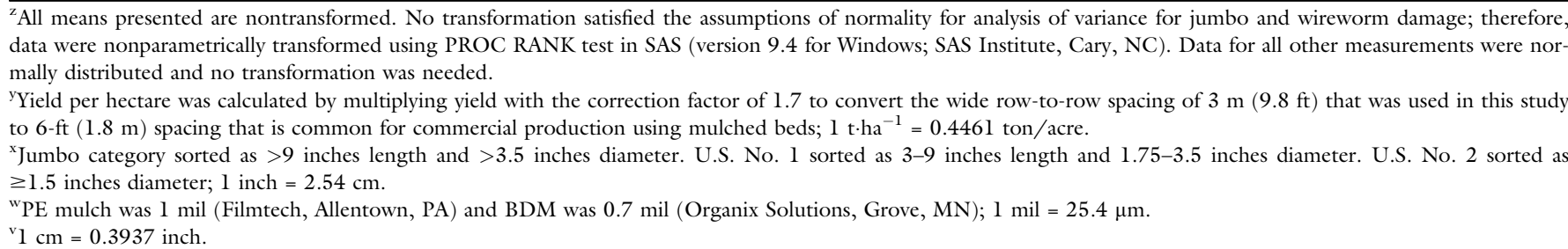 } \\
\hline
\end{tabular}


Table 6. Storage root yield per plant, total yield, number per plant, percent of storage roots with wireworm damage, and number of holes per storage root caused by wireworm, for six sweetpotato accessions planted at Washington State University Northwestern Washington Research and Extension Center, Mount Vernon, WA, in 2020. Because the study was not replicated, data are not statistically analyzed.

\begin{tabular}{|c|c|c|c|c|c|}
\hline Accession no. ${ }^{\mathrm{z}}$ & Yield per plant $(\mathrm{kg})^{\mathrm{y}}$ & Total yield $\left(t \cdot h a^{-1}\right)^{x}$ & $\begin{array}{l}\text { Storage roots } \\
\text { (no./plant) }\end{array}$ & $\begin{array}{c}\text { Wireworm damage } \\
(\%)\end{array}$ & $\begin{array}{c}\text { Wireworm holes } \\
\text { (no./root) }\end{array}$ \\
\hline PI 666141 & 2.22 & 32.5 & 4 & 14 & 3.4 \\
\hline W382 & 0.73 & 10.7 & 5 & 11 & 2.4 \\
\hline $04-284$ & 0.87 & 12.7 & 5 & 40 & 2.8 \\
\hline $04-791$ & 4.00 & 58.5 & 4 & 4 & 4.0 \\
\hline
\end{tabular}

${ }^{\mathrm{z}}$ Accessions obtained from the U.S. Department of Agriculture, Agricultural Research Service (P.A. Wadl).

${ }^{\mathrm{y}}$ Plants were spaced $38 \mathrm{~cm}$ (15.0 inches) apart in a single row; $1 \mathrm{~kg}=2.2046 \mathrm{lb}$.

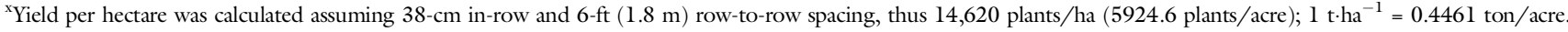

$\left(20.4 \mathrm{t} \cdot \mathrm{ha}^{-1}\right), 38-\mathrm{cm}$ had the lowest total yield $\left(17.0 \mathrm{t} \cdot \mathrm{ha}^{-1}\right)$, and $30-\mathrm{cm}$ was intermediate $\left(18.0 \mathrm{t} \cdot \mathrm{ha}^{-1}\right)$. There was no interaction between mulch and plant spacing $(P=0.19)$. Average marketable yield was $13.9 \mathrm{t} \cdot \mathrm{ha}^{-1}$ and did not differ due to mulch or plant spacing $[P=0.06$ and $P=0.25$, respectively (Table 5)], and there was no interaction between mulch and plant spacing $(P=0.28)$. In the no-mulch reference plot, total storage root yield $\left(5.8 \mathrm{t} \cdot \mathrm{ha}^{-1}\right)$ and marketable root yield $\left(2.9 \mathrm{t} \cdot \mathrm{ha}^{-1}\right)$ were $69 \%$ and $79 \%$ less than with mulch, respectively. Average storage root number per plant was 3.0 and did not differ due to mulch $(P=$ $0.18)$, there was a difference due to plant spacing $(P=0.006)$, but there was no interaction between mulch and plant spacing $(P=0.15)$. The greatest number of storage roots was produced at $38-\mathrm{cm}$ spacing (3.4) (Table 5). In the no-mulch reference plot, average storage root number per plant was $59 \%$ less than with mulch.

When storage roots were sorted by size, the weight of storage roots in the jumbo category differed due to mulch and spacing $(P=0.004$ and $P=0.04$, respectively), but there was no interaction between mulch and spacing $(P=0.17)$. There were more jumbo sweetpotatoes with $\mathrm{PE}$ mulch $\left(3.4 \mathrm{t} \cdot \mathrm{ha}^{-1}\right)$ and with $30-\mathrm{cm}$ spacing $\left(3 \mathrm{t} \cdot \mathrm{ha}^{-1}\right)$. Average yield of U.S. No. 1 grade and U.S. No. 2 sweetpotatoes was 4.1 and $7.8 \mathrm{t} \cdot \mathrm{ha}^{-1}$, respectively, and there were no differences due to mulch $(P=0.30$ and $P=0.39$, respectively). The weight of U.S. No. I grade sweetpotatoes also did not differ due to spacing $(P=0.64)$; however, the weight of U.S. No. 2 grade was greatest with $20-\mathrm{cm}$ spacing $\left[10.2 \mathrm{t}^{-h^{-1}}(P=0.008)\right]$. There was no interaction between mulch and plant spacing $(P=0.27$ and $P=0.54$, respectively) for total yield. In 2020 , the greatest total yield of storage roots was obtained for accession 04-791 (4 $\mathrm{kg}$ per plant, $\left.58.5 \mathrm{t} \cdot \mathrm{ha}^{-1}\right)$ and was lowest for accession 04-136 $(0.42 \mathrm{~kg}$ per plant, $6.1 \mathrm{t} \cdot \mathrm{ha}^{-1}$ ) (Table 6). The greatest storage root number per plant was obtained for accession 09130 (10), and the storage root number per plant was comparable for all other accessions (4.4 on average).

In 2019 , the proportion of storage roots with wireworm damage did not differ due to mulch $(P=0.80)$ or plant spacing $(P=0.38)$ (Table 5$)$, and there was no interaction between mulch and plant spacing $(P=0.81)$. Average wireworm damage was $98 \%$ overall and essentially all storage roots were observed to be severely damaged, with more than 10 to 20 wireworm holes per storage root (data not shown). In 2020, accession 04-284 had the greatest proportion of storage roots with wireworm damage $(40 \%)$ and accessions 04-791 and 04-136 had the least damage $(4 \%$ and $7 \%$, respectively). For the storage roots that had wireworm damage, the average number of holes per root was greatest for accessions 09-130 and 04-791 (4.0 for both) and lowest for accession 04-136 (1.7), followed by W382 (2.4). Four accessions produced marketable storage roots, whereas accessions 04-136 and 04-791 produced irregularly shaped storage roots that would not be marketable.

\section{Discussion and conclusions}

This study demonstrates there is potential to grow sweetpotatoes in northwest Washington for local fresh and processing markets; however, there are several limitations to production that must be addressed. First, a reliable supply of sweetpotato slips is needed for the region. Sweetpotato slips were $4 \mathrm{~d}$ in transit from North Carolina to Mount Vernon in 2019; they arrived in very poor condition, and $60 \%$ to $70 \%$ died after transplanting in the field. Slips likely were damaged during transport because of tissue desiccation and/or extreme temperatures (Gilbertson and Bradshaw, 1985; McKay, 1996). For sweetpotato production to be a viable crop, slips must be sourced closer to our region, for example from California where sweetpotatoes are being grown commercially. It also may be economically effective for growers to produce their own slips or arrange to have them produced in their region.

A second limitation to sweetpotato production in the region was severe wireworm damage that caused the crop to be nonmarketable in 2019 in this study. There was less wireworm damage to sweetpotatoes in 2020 , suggesting the wireworm-resistant accessions were effective. In 2019, $98 \%$ of storage roots were observed to be severely damaged, with more than 10 to 20 wireworm holes per storage root. In $2020,16 \%$ of the storage roots were damaged on average, with 1.7 to 4.0 holes per storage root. Both years, other crops such as lettuce (Lactuca sativa) and potatoes had extensive wireworm damage in plots adjacent to this study; therefore, wireworm damage in 2019 was not likely due to poor slip condition. Accessions PI 666141, W382, 04-284, and 09130 produced marketable storage roots, whereas accessions 04-136 and 04-791 produced irregularly shaped storage roots that would not be 
marketable. In addition to causing sweetpotatoes to be nonmarketable, wireworm feeding holes can be an entry point for plant pathogens that cause root rot (Ester and Huiting, 2007). Wireworms are difficult to manage, as their behavior can be unpredictable and the most effective insecticides were deregistered because they were persistent chlorinated hydrocarbons (Kuhar et al., 2003; Kwon et al., 1999; Parker and Howard, 2001; Schalk et al., 1993). Currently, growers depend solely on chemical insecticides that do not provide complete control of wireworm (Jackson et al., 2012; Lawrence et al., 2005). Another consideration is the mode of pesticide application, as the choice of products that would be applied in-season are limited by the production system. For example, if plastic mulch is in place, products that can be applied through the drip irrigation system can be used, or products can be target sprayed over the bed if soil is exposed in the transplant hole and before the canopy becomes too large. Breeding for pest resistance is one of the fundamental approaches to pest management, and results of this study suggest that resistant accessions may provide effective control of wireworm damage in sweetpotatoes. However, additional studies of these accessions to test their wireworm resistance are needed.

A third consideration for successful sweetpotato production in northern regions of the United States is increasing field soil temperature. PE mulch and BDM raised soil temperature by 2 to $3{ }^{\circ} \mathrm{C}$ at $10-\mathrm{cm}$ depth compared with the no-mulch reference bed in this study. This result is in line with other studies at this location (Cowan et al., 2014; Ghimire et al., 2018, 2020; Miles et al., 2012). Plant stand, the length of the longest vine, canopy cover, total storage root yield, marketable root yield, and average storage root number were all greater when sweetpotatoes were grown with plastic mulch than no-mulch. Furthermore, no jumbo or U.S. No. 1 grade sweetpotatoes were produced in the no-mulch reference bed. These results indicate that at this location, sweetpotato plants become established and grow more quickly with mulch than with no-mulch, likely because of the increased soil temperature. Although mulch type (PE, BDM) did not significantly affect total yield (18.5 $\mathrm{t} \cdot \mathrm{ha}^{-1}$ on average) or marketable yield (13.9 $\mathrm{t} \cdot \mathrm{ha}^{-1}$ on average), growers need to consider that yield was 7 $\mathrm{t} \cdot \mathrm{ha}^{-1}$ more with PE mulch than with BDM. Further, there were almost seven times more jumbo sweetpotatoes produced with $\mathrm{PE}$ mulch than with BDM, likely because of the $1{ }^{\circ} \mathrm{C}$ greater soil temperature throughout the season with PE mulch than with $\mathrm{BDM}$, as there were no differences in plant growth. Although BDM deterioration reached $11 \%$ by the end of the season, no differences were observed in weed suppression between PE mulch and BDM. A disadvantage of $\mathrm{PE}$ mulch is that it must be removed before harvest. In contrast, BDM does not need to be removed or disposed at the end of the season, and in this study, the BDM posed no issues with mechanical harvest. Most of the BDM remained in the plots when the harvester lifted the sweetpotatoes, and the BDM pieces that were lifted onto the harvester conveyer belt were returned to the field along with soil as the harvester belt rotated. These results indicate that BDM is a suitable alternative to PE mulch for fresh market sweetpotato production, although jumbo-grade sweetpotatoes for processing may be reduced with BDMs.

Plant spacing had minimal impact on plant growth measured by the length of the longest vine. Although plants grown with closer spacing had greater percent canopy cover later in the season, this was likely because of intermingling of vines from adjacent plants. In contrast, the intermediate canopy cover of plants grown with $38-\mathrm{cm}$ in-row spacing was likely because of an increase in the number of secondary vines formed per plant (Somda and Kays, 1990). Plant spacing did have an impact on storage root size and number, which are important production considerations. The $20-\mathrm{cm}$ plant spacing produced the greatest total storage root yield per hectare but lowest number of storage roots per plant, whereas $38-\mathrm{cm}$ plant spacing produced the lowest total storage root yield per hectare but the greatest number of storage roots per plant. Mortley et al. (1991) also found that increasing in-row spacing from 13 to $38 \mathrm{~cm}$ increased the number of storage roots per plant, and similarly, Wees et al. (2016) found increased yield per plant of 'Beauregard' sweetpotato with wider spacing when grown with BDM. Other studies reported that total yield of sweetpotatoes generally increased as in-row plant spacing decreased (Anderson et al., 1945; Peterson, 1961; Schultheis et al., 1999). In contrast, Guertal and Kemble (1997) and Arancibia et al. (2014) reported little or no effect of in-row spacing on marketable yield of 'Beauregard' and 'Evangeline' sweetpotatoes.

The size of sweetpotato storage roots is an important consideration for marketing. In our study, the yield of U.S. No. 1 grade sweetpotatoes did not differ due to spacing, whereas the yield of jumbo sweetpotatoes was greatest with a $30-\mathrm{cm}$ spacing $\left(3 \mathrm{t} \cdot \mathrm{ha}^{-1}\right)$ and yield of U.S. No. 2 grade sweetpotatoes was greatest with a $20-\mathrm{cm}$ plant spacing $\left(10.2 \mathrm{t} \cdot \mathrm{ha}^{-1}\right)$. Wider plant spacing generally produces a greater number of larger storage roots, whereas narrower plant spacing produces more smaller storage roots (Swiader et al., 1992). In other studies, it has been shown that it can take longer for storage roots to increase in size with smaller in-row spacing. For example, in North Carolina, 'Beauregard' sweetpotato planted at $38-\mathrm{cm}$ in-row spacing reached optimal yield of U.S. No. 1 grade in $\approx 90$ $\mathrm{d}, 110 \mathrm{~d}$ at a $25-\mathrm{cm}$ in-row spacing, and $130 \mathrm{~d}$ at $15-\mathrm{cm}$ in-row spacing K.V. Pecota, personal communication). No. 1-grade storage roots are the most desired for fresh market with the greatest monetary return, whereas jumbo-grade storage roots are marketable for processing such as sweetpotato puree, but they have an increased risk of chilling injury, which can shorten storage life (Schultheis et al., 1999; Wees et al., 2016). Results from our study and others demonstrate there is a tradeoff and a balance between total yield and plant density such that overall yields can be greater at higher plant density, whereas individual yield per plant is reduced. Thus, the target market must be considered when selecting in-row spacing; and in regions with shorter growing seasons, wider in-row spacing may be needed to ensure higher yield.

In this study, the overall average total yield of 'Covington' sweetpotato in 2019 was $18.5 \mathrm{t} \cdot \mathrm{ha}^{-1}$ and marketable yield was $13.9 \mathrm{t} \cdot \mathrm{ha}^{-1}$, a loss of $\approx 25 \%$ because of off-shaped, cracked, 
and undersized roots. This total yield was less than the national average of 11 tons/acre (24.7 $\left.\mathrm{t} \cdot \mathrm{ha}^{-1}\right)$ and was likely a result of the unhealthy slips that were planted in 2019 and that took a few months to become well established. In 2020, total yield of the highest-yielding accessions was 32.5 to $58.5 \mathrm{t} \cdot \mathrm{ha}^{-1}$, likely because of healthy transplants that were propagated onsite, but may also have been due to a cultivar effect. In New Hampshire, 'Covington' sweetpotato produced 405 to $74750-\mathrm{lb}$ bushels/acre (22.7 to $41.9 \mathrm{t} \cdot \mathrm{ha}^{-1}$ ) when grown with BDM and 24,000 plants/ha with 9-inch $(22.9 \mathrm{~cm})$ in-row spacing (Sideman, 2015). In contrast, in Quebec, Canada, Wees et al. (2015) found poor total and marketable yields for 'Covington' sweetpotato (14 and $9 \mathrm{t} \cdot \mathrm{ha}^{-1}$, respectively), whereas marketable yield of other cultivars ranged between 18 and $25 \mathrm{t} \cdot \mathrm{ha}^{-1}$. Although 'Covington' sweetpotato is currently the most common cultivar grown in North Carolina, it may not be the best cultivar for northern regions of the United States.

Sweetpotato yields have the potential to be high in northern latitude regions because of the longer photoperiod during the growing season that increases growth of the storage roots (Lebot, 2009). In growth chamber experiments, sweetpotato root number was greater with photoperiods of 15 to $21 \mathrm{~h}$ per day compared with $12 \mathrm{~h}$, and storage root yield almost doubled when daylength was increased from 9 to $18 \mathrm{~h}$ (Mortley et al., 1996). The establishment stage of sweetpotato is the first 4 weeks after planting, and is considered the most critical phase in the growing cycle because plant development during this time largely determines later plant growth and yield (Pardales and Esquibel, 1996). Thus, at high latitudes, such as Mount Vernon, where daylength is $16 \mathrm{~h}$ on average in June and July, rapid growth during establishment of healthy transplants likely contributes to higher yields.

In conclusion, marketable sweetpotato yield that is similar to the southern United States can be produced in northwest Washington with $\mathrm{PE}$ mulch and BDM. Although the yield in this study in 2019 was lower than the national average, this was likely a result of unhealthy slips and highlights the importance of healthy slips for successful sweetpotato production. Wireworm can be a major pest affecting sweetpotatoes grown in this region, and the greater-thannational-average yield of wirewormresistant accessions in 2020 opens the door for further research focusing on wireworm-resistant sweetpotato cultivars suitable for northwest Washington. The three plant spacings tested in this study $(20,30$, and $38 \mathrm{~cm})$ produced equal yield of U.S. No. 1 storage roots; however, the greatest total yield with more U.S. No. 2 grade storage roots was produced at $20-\mathrm{cm}$ spacing and more jumbo storage roots were produced at a $30-\mathrm{cm}$ spacing. These results indicate a $20-\mathrm{cm}$ in-row spacing is suitable for the greatest production of roots for fresh market and for sweetpotato fries, whereas a $30-\mathrm{cm}$ in-row spacing is suitable for the processing puree market. Overall, sweetpotatoes appear to be suitable for production in northwest Washington, and future research should evaluate cultivars with maximum adaptation to the region, techniques to reduce wireworm damage including genetic resistance, and the economics of producing sweetpotatoes in our region.

\section{Literature cited}

AgWeatherNet. 2020. The Washington Agricultural Weather Network. 4 Feb. 2021. <http://weather.wsu.edu/>.

Anderson, W.S., H.L. Cochran, J.B. Edmond, O.B. Garrison, R.E. Wright, and V.R. Boswell. 1945. Regional studies of time of planting and hill spacing of sweet potatoes. U.S. Dept. Agr. Circ. 725.

Anzalone, A., A. Cirujeda, J. Aibar, G. Pardo, and C. Zaragoza. 2010. Effect of biodegradable mulch materials on weed control in processing tomatoes. Weed Technol. 24:369-377, https://doi.org/ 10.1614/WT-09-020.1.

Arancibia, R.A., C.D. Smith, D.R. LaBonte, J.L. Main, T.P. Smith, and A.Q. Villordon. 2014. Optimizing sweetpotato production for fresh and processing markets through plant spacing and plantingharvest time. HortTechnology 24:16-24, https://doi.org/10.21273/HORTTECH. 24.1.16.

Brandenberger, L., J. Shrefler, E. Rebek, and J. Damicone. 2014. Sweet potato production. Oklahoma Coop. Ext. Serv. HLA6022. 6 July 2021. <https://extension. state.edu/fact-sheets/print-publications/hla/ sweet-potato-production-hla-6022.pdf $>$.
Coolong, T., K. Seebold, R. Bessin, T. Woods, and S. Fannin. 2012. Sweetpotato production for Kentucky. Univ. Kentucky College Agr. Coop. Ext. Serv. ID-195. 15 July 2021. <http://www2. ca.uky.edu/agcomm/pubs/id/id195/ id195.pdf $>$.

Cowan, J.S., C.A. Miles, P.K. Andrews, and D.A. Inglis. 2014. Biodegradable mulch performed comparably to polyethylene in high tunnel tomato (Solanum lycopersicum L.) production. J. Sci. Food Agr. 94:1854-1864, https://doi.org/ 10.1002 /jsfa.6504.

Cuthbert, F.P. 1967. Insects affecting sweetpotatoes. Agr. Res. Serv., U.S. Dept. Agr., Washington, DC.

Duque, L.O. 2020. Performance of sweetpotato varieties grown using black plastic mulch in Pennsylvania. HortTechnology 30:797-802, https://doi.org/ 10.21273/HORTTECH04689-20.

Ester, A. and H. Huiting. 2007. Controlling wireworms (Agriotes spp.) in a potato crop with biologicals. IOBC/wprs Bul. 30:189-196. 18 Aug. 2021. <http:// www.iobc-wprs.org/pub/bulletins/iobcwprs_bulletin_2007_30_01.pdf\#page=188 $>$.

Food and Agriculture Organization of the United Nations. 2019. Crops and livestock products. 29 Sept. 2021. <http:// www.fao.org/faostat/en/\#compare $>$.

Ghimire, S., A.L. Wszelaki, J.C. Moore, D.A. Inglis, and C.A. Miles. 2018. Use of biodegradable mulches in pie pumpkin production. HortScience 53:288-294, https://doi.org/10.21273/HORTSCI 12630-17.

Ghimire, S., E. Scheenstra, and C.A. Miles. 2020. Soil-biodegradable mulches for growth, yield, and quality of sweet corn in a Mediterranean-type climate. HortScience 55:317-325, https://doi. org/10.21273/HORTSCI14667-19.

Gilbertson, P. and A.D. Bradshaw. 1985. Tree survival in cities: The extent and nature of the problem. Arboric. J. 9:131-142 (abstr.), https://doi.org/ 10.1080/03071375.1985.9746706.

Guertal, E.A. and J.A. Kemble. 1997. Nitrogen rate and within-row plant spacing effects on sweetpotato yield and grade. J. Plant Nutr. 20:355-360 (abstr.), https://doi.org/10.s1080/01904169709 365256.

Jackson, D.M., H.F. Harrison, Jr., and J.R. Ryan-Bohac. 2012. Insect resistance in sweetpotato plant introduction accessions. J. Econ. Entomol. 105:651-658, https://doi.org/10.1603/ecl1307.

Jennings, K., L. Quesada-Ocampo, J. Schultheis, A. Woodley, C. Yencho, K. 
Pecota, A. Huseth, S.C. Smith, and M. Boyette. 2019. Crop production management - Sweetpotatoes. North Carolina organic commodities production guide. 6 July 2021. <https://content. ces.ncsu.edu/north-carolina-organiccommodities-production-guide/chapter8 -crop-production-management-sweet potatoes $>$.

Johnson, T., N. Wilson, M.R. Worosz, D. Fields, and J.K. Bond. 2015. Vegetables and pulses outlook: Special article. U.S. Dept. Agr., Econ. Res. Serv. VGS-355SAl. 3 Sept. 2021. <https://www.ers.usda. gov/webdocs/outlooks/39544/52774_vgs355-sal.pdf? $\mathrm{v}=6656.5>$.

Kuhar, T.P., J. Speece, III, J. Whalen, J.M. Alvarez, A. Aloykhin, G. Ghidiu, and M.R. Spellman. 2003. Current status of insecticidal control of wireworms in potatoes. Pestic. Outlook 14:265-267, https://doi.org/10.1039/B314851N.

Kwon, M., Y.I. Hahm, K.Y. Shin, and Y.J. Ahn. 1999. Evaluation of various potato cultivars for resistance to wireworms (Coleoptera: Elateridae). Amer. J. Potato Res. 76:317-319, https://doi. org/10.1007/BF02853631.

Lawrence, J., S. Tolin, C. Edwards, S. Fleischer, D.M. Jackson, D. Clarke-Harris, S. McDonald, K. Dalip, and P. Chung. 2005. Developing IPM packages in the Caribbean, p. 95-119. In: G.W. Norton, E.A. Heinrichs, G.C. Luther, and M.E. Irwin (eds.). Globalizing integrated pest management: A participatory research process. Blackwell Publ., Ames, IA.

Lebot, V. 2009. Tropical root and tuber crops: Cassava, sweet potato, yams and aroids. 2nd ed. CABI, Wallingford, UK, http://dx.doi.org/ $10.1079 / 9781845934248.0000$.

Martin-Closas, L., M.A. Bach, and A.M. Pelacho. 2008. Biodegradable mulching in an organic tomato production system. Acta Hort. 767:267-274, https://doi. org/10.17660/ActaHortic.2008.767.28.

McKay, H.M. 1996. A review of the effect of stresses between lifting and planting on nursery stock quality and performance. New For. 13:363-393, https:// doi.org/10.1023/A:1006563130976.

Miles, C., R. Wallace, A. Wszelaki, J. Martin, J. Cowan, and D.A. Inglis. 2012. Deterioration of potentially biodegradable alternatives to black plastic mulch in three tomato production regions. HortScience 47:1270-1277, https://doi.org/10.21273/ HORTSCI.47.9.1270.

Moreno, M.M. and A. Moreno. 2008. Effect of different biodegradable and polyethylene mulches on soil properties and production in a tomato crop. Scientia Hort. 116:256-263, https://doi.org/ 10.1016/j.scienta.2008.01.007.

Mortley, D.G., P.A. Loretan, C.K. Bonsi, W.A. Hill, and C.E. Morris. 1991. Plant spacing influences yield and linear growth rate of sweetpotatoes grown hydroponically. HortScience 26:1274-1275, https://doi. org/10.21273/HORTSCI.26.10.1274.

Mortley, D.G., P.A. Loretan, W.A. Hill, C.K. Bonsi, and C.E. Morris. 1996. Growth responses of hydroponically grown sweetpotato tolerant and intolerant of a continuous daily light period. HortScience 31:209-212, https://doi. org/10.21273/HORTSCI.31.2.209.

Ontario Ministry of Agriculture, Food and Rural Affairs. 2012. Sweet potatoes. 4 Sept. 2021. <http://www.omafra.gov.on.ca/ CropOp/en/spec_veg/root_tuber_veg/sp. html\#>.

Onunka, N.A., G. Antai, B.N. Onunka, and S.C. Njoku. 2011. Effect of plant density and land race on the growth and yield of sweetpotato in Northern Guinea savanna of Nigeria. J. Agr. Soc. Res. 11:164-172

Parker, W.E. and J.J. Howard. 2001. The biology and management of wireworms (Agriotes spp.) on potato with particular reference to the U.K. Agr. For. Entomol. 3:85-98, https://doi. org/10.1046/j.1461-9563.2001.00094.x.

Pardales, J.R., Jr. and C.B. Esquibel. 1996. Effect of drought during the establishment period on the root system development of cassava. Jpn. J. Crop. Sci. 65:93-97, https://doi.org/10.1626/pps.2.247.

Patrignani, A. and T.E. Ochsner. 2015. Canopeo: A powerful new tool for measuring fractional green canopy cover. Agron. J. 107:2312-2320, https://doi. org/10.2134/agronj15.0150.

Peel, M.C., B.L. Finlayson, and T.A. Mcmahon. 2007. Updated world map of the Köppen-Geiger climate classification. Hydrol. Earth Syst. Sci. 11:1633-1644, https://doi. org/10.5194/hess-11-1633-2007.

Peterson, L.E. 1961. The varietal response of sweetpotato to changing levels of irrigation, fertilizer, and plant spacing. Proc. Amer. Soc. Hortic. Sci. 77:452-457 (abstr.).

Schalk, J.M., J.R. Bohac, P.D. Dukes, and W.R. Martin. 1993. Potential of nonchemical control strategies for reduction of soil insect damage in sweetpotato. J. Amer. Soc. Hort. Sci. 118:605-608, https://doi.org/10.21273/JASHS.118. 5.605 .

Schultheis, J.R., S.A. Walters, D.E. Adams, and E.A. Estes. 1999. In-row plant spacing and date of harvest of 'Beauregard' sweetpotato affect yield and return on investment. HortScience 34:1229-1233, https:// doi.org/10.21273/HORTSCI.34.7.1229.

Seal, D.R., A.B. Baniya, R. DyrdahlYoung, R.C. Hochmuth, N.C. Leppla, D.K. Fenneman, R.T. Broughton, and P. DiGennaro. 2020. Wireworm (Coleoptera: Elateridae) species composition and management in sweet potato grown in north Florida using chemical insecticides and entomopathogenic nematodes. Environ. Entomol. 49:1415-1426, https:// doi.org/10.1093/ee/nvaal13.

Sideman, R.G. 2015. Performance of sweetpotato cultivars grown using biodegradable black plastic mulch in New Hampshire. HortTechnology 25:412-416, https://doi.org/10.21273/HORTTECH. 25.3.412.

Sintim, H.Y., S. Bandopadhyay, M.E. English, A.I. Bary, J.M. DeBruync, S.M. Schaeffer, C.A. Miles, J.P. Reganold, and M. Flury. 2019. Impacts of biodegradable plastic mulches on soil health. Agr. Ecosyst. Environ. 273:36-49, https://doi. org/10.1016/j.agee.2018.12.002.

Smith, T.P. 2006. Biology and chemical ecology of the sugarcane beetle and integrated pest management of sweet potato soil insects in Louisiana. Louisiana State Univ., PhD Diss. 3704. 6 Sept. 2021. $<$ https://digitalcommons.lsu.edu/cgi/ viewcontent .cgi article $=4703 \&$ context $=$ gradschool_dissertations $>$.

Somda, Z.C. and S.J. Kays. 1990. Sweet potato canopy architecture: Branching pattern. J. Amer. Soc. Hort. Sci. 115: 33-38, https://doi.org/10.21273/JASHS. 115.1.33.

Sorensen, K.A. 2009. Sweetpotato insects: Identification, biology and management, $\mathrm{p}$. 161-188. In: G. Loebenstein and G. Thottappilly (eds.). The sweetpotato. Springer, Dordrecht, Netherlands, https://doi.org/ 10.1007/978-1-4020-9475-0_10.

Swiader, J.M., G.W. Ware, and J.P. McCollum. 1992. Producing vegetable crops. 4th ed. Interstate, Danville, IL.

Tofanelli, M.B. and S.E. Wortman. 2020. Benchmarking the agronomic performance of biodegradable mulches against polyethylene mulch film: A meta-analysis. Agronomy (Basel) 10:1618, https://doi. org/10.3390/agronomy10101618.

Truong, V.D., R.Y. Avula, K.V. Pecota, and G.C. Yencho. 2018. Sweetpotato production, processing, and nutritional quality, p. 811-838. In: M. Siddiq and M.A. Uebersax (eds.). Handbook of vegetables and vegetable processing. 2nd ed. Wiley, Hoboken, NJ.

U.S. Department of Agriculture, Agricultural Marketing Service. 2005. United 
States standards for grades of sweet potatoes. 8 Aug. 2021. <https://www.ams. usda.gov/grades-standards/sweetpotatoesgrades-and-standards $>$.

U.S. Department of Agriculture, National Agricultural Statistics Service. 2020. Vegetables 2019 summary. 8 Aug. 2021. <https://www.nass.usda.gov/Publications/ Todays_Reports/reports/vegean20.pdf $>$.

U.S. Department of Agriculture, Natural Resource Conservation Service. 1960. Soil survey: Skagit County Washington. 3 Sept. 2021. $<$ https://www.nrcs.usda.gov/Internet/FSE_
MANUSCRIPTS/washington/skagit WA1960/skagitWA1960.pdf $>$.

Waterer, D. 2010. Evaluation of biodegradable mulches for production of warm-season vegetable crops. Can. J. Plant Sci. 90:737-743, https://doi.org/ 10.4141/CJPS10031.

Wees, D., P. Seguin, J. Boisclair, and C. Gendre. 2015. Performance and quality of sweetpotato cultivars grown in Quebec, Canada with biodegradable plastic mulch. HortTechnology 25:815-823, https://doi. org/10.21273/HORTTECH.25.6.815.
Wees, D., P. Seguin, and J. Boisclair. 2016. Sweet potato production in a shortseason area utilizing black plastic mulch: Effects of cultivar, in-row plant spacing, and harvest date on yield parameters. Can. J. Plant Sci. 96:139-147, https://doi. org/10.1139/cjps-2015-0150.

Zhang, H., L.W. DeVetter, E. Scheenstra, and C. Miles. 2020. Weed pressure, yield, and adhesion of soilbiodegradable mulches with pie pumpkin (Cucurbita pepo). HortScience 55:1014-1021, https://doi. org/10.21273/HORTSCI15017-20. 